\title{
Physiology of 'Paluma' guava under irrigation with saline water and nitrogen fertilization
}

\author{
Fisiologia de goiabeira 'Paluma' sob irrigação com água salina e \\ adubação nitrogenada
}

\author{
Evandro Manoel da Silva ${ }^{1 *}$; Reginaldo Gomes Nobre ${ }^{2}$; Leandro de Pádua Souza ${ }^{1}$; \\ Francisco Wesley Alves Pinheiro ${ }^{3}$; Geovani Soares de Lima ${ }^{4}$; \\ Hans Raj Gheyi ${ }^{5}$; Luana Lucas de Sá Almeida ${ }^{6}$
}

\begin{abstract}
The use of saline water in irrigation causes osmotic and toxic effects and nutritional imbalance in plants, leading to morphophysiological modifications in the leaves and compromising the production of photosynthetic pigments, which negatively reflects in the growth and development of the crops. Hence, this study aimed to evaluate the effect of irrigation water salinity on the content of photosynthetic pigments and leaf morphophysiology of guava seedlings cv. 'Paluma' under nitrogen $(\mathrm{N})$ fertilization. A randomized block design was used, testing five levels of irrigation water electrical conductivity $\mathrm{ECw}\left(0.3,1.1,1.9,2.7\right.$, and $\left.3.5 \mathrm{dS} \mathrm{m}^{-1}\right)$ and four $\mathrm{N}$ doses $(541.1,773.0,1,004.9$, and 1,236.8 $\mathrm{mg}$ of $\mathrm{N}$ $\mathrm{dm}^{-3}$ of soil) in a $5 \times 4$ factorial scheme with three replicates and five plants per plot. The contents of photosynthetic pigments in the leaves of the guava seedlings cv. 'Paluma' were inhibited by the increase in irrigation water salinity at 190 days after emergence, and the salt stress was lessened with the $\mathrm{N}$ dose of $1,004.9 \mathrm{mg} \mathrm{dm}^{-3}$ up to an ECw level of $1.2 \mathrm{dS} \mathrm{m}^{-1}$. Leaf morphophysiology of guava seedlings was not compromised by irrigation water salinity up to $1.5 \mathrm{dS} \mathrm{m}^{-1}$, and the highest values were obtained in plants fertilized with $541.1 \mathrm{mg}$ of $\mathrm{N} \mathrm{dm}^{-3}$.
\end{abstract}

Key words: Psidium guajava L. Photosynthesis. Salinity and nitrogen.

\section{Resumo}

O uso de água salina na irrigação promove efeitos osmóticos, tóxicos e desbalanço nutricional nas plantas, causando modificações morfofisiológicas nas folhas e comprometimento na produção dos pigmentos fotossintéticos, refletindo negativamente no crescimento e desenvolvimento das culturas. Nesse sentido, objetivou-se com o presente trabalho avaliar o efeito da salinidade da água de irrigação no teor de pigmentos fotossintéticos e na morfofisiológica foliar de mudas de goiabeira cv. Paluma sob adubação nitrogenada. Usou-se a aleatorização em blocos, testando cinco níveis de condutividade elétrica da água de irrigação - CEa $\left(0,3 ; 1,1 ; 1,9 ; 2,7\right.$ e 3,5 dS m $\left.{ }^{-1}\right)$ e quatro doses de nitrogênio $(541,1 ; 773,0 ; 1004,9$ e $1236,8 \mathrm{mg}$ de $\mathrm{N} \mathrm{dm}^{-3}$ de solo), em esquema fatorial 5 x 4, com três repetições e cinco plantas por parcela. Os teores de

${ }^{1}$ Discentes do Curso de Doutorado do Programa de Pós-Graduação em Engenharia Agrícola, Universidade Federal de Campina Grande, UFCG, Centro de Tecnologia e Recursos Naturais, Campina Grande, PB, Brasil. E-mail: evandroagroman@hotmail. com; engenheiropadua@hotmail.com

2 Prof., Unidade Acadêmica de Ciências Agrárias, UFCG, Pombal, PB, Brasil. E-mail: rgomesnobre@yahoo.com.br

${ }^{3}$ Discente do Curso de Graduação em Agronomia, UFCG, Centro de Ciências e Tecnologia Agroalimentar, Pombal, PB. E-mail: wesley.ce@hotmail.com

${ }^{4}$ Bolsista do Programa Nacional de Pós-Doutorado, PNPD/CAPES, UFCG, Centro de Tecnologia e Recursos Naturais, Campina Grande, PB, Brasil. E-mail: geovanisoareslima@gmail.com

5 Prof. Visitante Nacional Sênior, CAPES, Universidade Federal do Recôncavo da Bahia, UFRB, Cruz das Almas, BA, Brasil. E-mail: hans@pq.cnpq.br

${ }^{6}$ Discente do Curso de Mestrado do Programa de Pós-Graduação em Horticultura Tropical, UFCG, Centro de Ciências e Tecnologia Agroalimentar, Pombal, PB, Brasil. E-mail: luana_lucas_15@hotmail.com

* Author for correspondence 
pigmentos fotossintéticos nas folhas das mudas de goiabeira cv. Paluma foram inibidos pelo aumento da salinidade na água de irrigação aos 190 dias após a emergência, sendo o estresse salino amenizado com

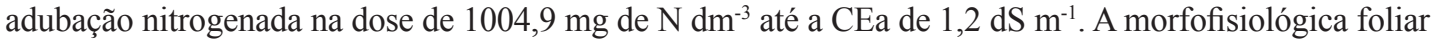
das mudas de goiabeira não foi comprometida pela salinidade da água de irrigação de até $1,5 \mathrm{dS} \mathrm{m}^{-1}$, e os

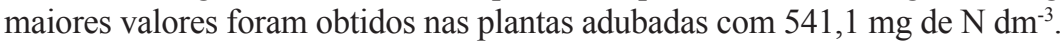

Palavras-Chave: Psidium guajava L. Fotossíntese. Salinidade e nitrogênio.

\section{Introduction}

In arid and semi-arid regions, irrigation emerges as one of the technologies that have most contributed to guaranteeing the production and exploitation of agricultural activities, because these areas are characterized by long drought periods. However, in these regions, water is not always of good quality, resulting in the use of irrigation water with different saline levels (HOLANDA et al., 2010).

The use of saline water in irrigation represents a serious issue in the agricultural production system, because of both the alterations in soil physical and chemical attributes (CAVALCANTE et al., 2010) and the negative impacts of the salts on the plants. These alterations are associated with osmotic and toxic effects, especially of $\mathrm{Na}^{+}$and $\mathrm{Cl}^{-}$, and with nutritional imbalance of $\mathrm{K}^{+}, \mathrm{Ca}^{2+}$, and $\mathrm{Mg}^{2+}$, induced by the competition with $\mathrm{Na}^{+}$, or even of $\mathrm{NO}_{3}{ }^{-}$due to the high concentration of $\mathrm{Cl}^{-}$in the environment, which damages the functions of the enzymatic systems and impedes protein synthesis (APSE; BLUMWALD, 2007; DIAS et al., 2012b).

Plant species differently respond to salt stress and, among the fruit crops of economic interest, guava (Psidium guajava L.) is one of the species whose growth is affected by the use of saline irrigation water, especially at an early growth phase, being even classified as sensitive to salinity, with a salinity threshold of $1.2 \mathrm{dS} \mathrm{m}^{-1}$ in the saturation extract, i.e., it suffers a decrease in its yield (TÁVORA et al., 2001). Some studies demonstrate that the increase in irrigation water salinity negatively affects leaf morphology of guava seedlings (CAVALCANTE et al., 2007, 2010) and, although not observed in this species, may decrease the concentration of photosynthetic pigments, which has been observed in leaves of passion fruit seedlings and tomato plants (CAVALCANTE et al., 2011; FREIRE et al., 2013; TATAGIBA et al., 2014).
For Cavalcante et al. (2010), the formation of seedlings and the cultivation of guava with saline irrigation water depends on the use of adequate techniques. In this case, the use of $\mathrm{N}$ fertilization emerges as a promising technology, because it reduces the $\mathrm{Cl} / \mathrm{N}$ ratio in the plant, reestablishing the nutritional balance (BLANCO et al., 2008). However, there are not many studies testing this method in guava crops under salt stress to evaluate the effects of salinity on the contents of photosynthetic pigments and on leaf morphophysiology.

Mineral nutrition is an important factor, and $\mathrm{N}$ is the second macronutrient required in large amounts by guava seedlings (FRANCO et al., 2007). When applied at adequate doses, $N$ increases the chlorophyll content in the leaves (DIAS et al., 2012a) due to its functions in plant metabolism, participating as a constituent of the chlorophyll molecule, nucleic acids, amino acids, and proteins (TAIZ; ZEIGER, 2013).

The quantification of chlorophyll contents and the evaluation of leaf morphophysiology are relevant in studies on fertilization practices, because they are related to the photosynthetic efficiency of the plants and, consequently, to their growth, production, and adaptability to different environmental conditions, such as salinity (TAIZ; ZEIGER, 2013). Therefore, this study aimed to evaluate the effect of irrigation water salinity on the contents of photosynthetic pigments and leaf morphophysiology of guava seedlings cv. 'Paluma' subjected to $\mathrm{N}$ doses.

\section{Material and Methods}

The experiment was carried out from March to October 2014 in a greenhouse at the Center of Sciences and Agrifood Technology (CCTA) of the 
Federal University of Campina Grande (UFCG), Pombal-PB, Brazil, 648'16" S, 3749'15" W, at a mean altitude of $144 \mathrm{~m}$ asl.

The treatments consisted of the combination of five levels of irrigation water salinity $(0.3,1.1$, $1.9,2.7$, and $\left.3.5 \mathrm{dS} \mathrm{m}^{-1}\right)$ and four $\mathrm{N}$ doses $(70,100$, 130 , and $160 \%$ of the $\mathrm{N}$ dose indicated for guava seedlings, i.e., 541.1, 773.0, 1,004.9, and 1,236.8 $\mathrm{mg}$ of $\mathrm{N} \mathrm{dm}^{-3}$ of soil), in randomized blocks with three replicates. Each experimental unit had five plants. The $\mathrm{N}$ doses were determined based on the dose of $773 \mathrm{mg}$ of $\mathrm{N} \mathrm{dm}^{-3}$, recommended by Dias et al. (2012a) for guava seedlings cv. 'Paluma' propagated from herbaceous cuttings, which corresponded to the $\mathrm{N}$ dose of $100 \%$.

Saline irrigation waters were prepared using local supply water with electrical conductivity $(\mathrm{ECw})$ of $0.3 \mathrm{dS} \mathrm{m} \mathrm{m}^{-1}$ by adding the amounts of $\mathrm{NaCl}, \mathrm{CaCl}_{2} \cdot 2 \mathrm{H}_{2} \mathrm{O}$, and $\mathrm{MgCl}_{2} \cdot 6 \mathrm{H}_{2} \mathrm{O}$ salts, to obtain equivalent proportions of $7: 2: 1$, which is the predominant salinity in the main water sources available in Northeast Brazil, following the relationship between $\mathrm{ECw}$ and the concentration of salts ( mmol $_{\mathrm{c}} \mathrm{L}^{-1}=\mathrm{EC} \times \mathrm{x}$ 10) (MEDEIROS, 1992).

The experiment was conducted using the guava cultivar 'Paluma', the most cultivated cultivar in Northeast Brazil (DIAS et al., 2012a). Three seeds per container were planted at a depth of $1.0 \mathrm{~cm}$. The containers consisted of plastic tubes with a height of $19 \mathrm{~cm}$, a diameter of $6.3 \mathrm{~cm}$ and a capacity of 288 $\mathrm{cm}^{3}$. Openings to allow drainage were located at the bottom. The containers were arranged on trays with a capacity for 54 tubes, supported by metal workbenches (angle brackets) at a height of $0.80 \mathrm{~m}$ from the soil.

The tubes were filled with substrate composed of Fluvic Neosol + sand + well decomposed bovine manure at the proportion of 82,15 , and $3 \%$, respectively. The physical and chemical characteristics of the substrate (Table 1) were analyzed at the Laboratory of Soils and Plants of the CCTA/UFCG, according to the methodology of Claessen (1997).

Table 1. Physical and chemical characteristics of the substrate used in the experiment.

\begin{tabular}{|c|c|c|c|c|c|c|c|c|c|}
\hline \multirow{3}{*}{$\begin{array}{l}\text { Textural } \\
\text { class }\end{array}$} & \multirow{3}{*}{$\begin{array}{c}\text { Apparent } \\
\text { density } \\
\mathrm{kg} \mathrm{dm}^{-3}\end{array}$} & \multirow{3}{*}{\multicolumn{2}{|c|}{$\begin{array}{c}\text { Total } \\
\text { porosity } \\
\%\end{array}$}} & \multirow{3}{*}{$\begin{array}{c}\text { Organic } \\
\text { matter } \\
\mathrm{g} \mathrm{kg}^{-1}\end{array}$} & \multirow{3}{*}{$\begin{array}{c}\mathrm{P} \\
\mathrm{mg} \mathrm{dm^{-3 }}\end{array}$} & \multicolumn{4}{|c|}{ Exchange complex } \\
\hline & & & & & & $\mathrm{Ca}^{2+}$ & $\mathrm{Mg}^{2+}$ & $\mathrm{Na}^{+}$ & $\mathrm{K}^{+}$ \\
\hline & & & & & & \multicolumn{4}{|c|}{-------- $\mathrm{cmol}_{\mathrm{c}} \mathrm{dm}^{-3}$} \\
\hline Sandy loam & 1.38 & & 47.00 & 32 & 17 & 5.4 & 4.1 & 2.21 & 0.28 \\
\hline \multicolumn{10}{|c|}{ Saturation extract } \\
\hline $\mathrm{pH}_{\mathrm{ps}}$ & $\begin{array}{l}\text { ECse } \\
\mathrm{dS} \mathrm{m^{-1 }}\end{array}$ & $\mathrm{Ca}^{2+}$ & $\mathrm{Mg}^{2+}$ & $\mathrm{K}^{+}$ & $\begin{array}{l}\mathrm{Na}^{+} \\
--\mathrm{mmol}_{\mathrm{c}} \mathrm{dr}\end{array}$ & $\begin{array}{cc}\mathrm{Cl}^{-} & \mathrm{SO}_{4}^{2-} \\
\mathrm{m}^{-3}\end{array}$ & $\mathrm{CO}_{3}^{2-}$ & $\mathrm{HCO}_{3}^{-}$ & $\begin{array}{c}\text { Saturation } \\
\%\end{array}$ \\
\hline 7.41 & 1.20 & 2.50 & 3.75 & 4.74 & 3.02 & 3.10 & 0.00 & 5.63 & 27.00 \\
\hline
\end{tabular}

Contents of $\mathrm{P}, \mathrm{K}$, and $\mathrm{Na}$ in soil determined in Mehlich-1 extractor; Exchangeable $\mathrm{Ca}$ and $\mathrm{Mg}$ extraction by $1.0 \mathrm{~mol} \mathrm{~L}^{-1} \mathrm{KCl}$; Organic matter: Walkley-Black wet digestion; $\mathrm{pHps}=\mathrm{pH}$ of the saturation paste; ECse = Electrical conductivity of the saturation extract of the substrate at $25^{\circ} \mathrm{C}$.

When plants showed two pairs of true leaves, fully expanded (20 days after emergence), thinning was performed, leaving only the most vigorous plant per tube.

Phosphate fertilization was performed at the dose of $100 \mathrm{mg}$ of $\mathrm{P}_{2} \mathrm{O}_{5} \mathrm{dm}^{-3}$ in the form of single superphosphate, which was ground and mixed with the substrate before sowing (CORRÊA et al., 2003).
In addition, potassium fertilization was applied, using the dose of $726 \mathrm{mg}$ of $\mathrm{K} \mathrm{dm}^{-3}$ of substrate (FRANCO et al., 2007), divided into four equal applications at 60, 90, 120, and 150 days after emergence (DAE) via fertigation with water of EC $=0.3 \mathrm{dS} \mathrm{m}^{-1}$ for all treatments.

Application of saline water began at $25 \mathrm{DAE}$ and irrigation of the different treatments was based 
on crop water requirement, determined through drainage lysimetry, i.e., the volume retained in the tube was daily applied, determined by the difference between the applied volume and the volume drained in the previous irrigation. Irrigation was performed twice a day, in the early morning and late afternoon. Every 15 days, a leaching fraction of 0.15 was applied based on the volume applied in this period in order to avoid accumulation of salts in the substrate.

Nitrogen $(\mathrm{N})$ fertilization began at 25 DAE, applied through fertigation and divided into 14 equal applications, every 10 days, using urea (45\% of $\mathrm{N}$ ) as $\mathrm{N}$ source.

The effect of the treatments on the plants was observed at 190 DAE through evaluation of the photosynthetic pigments: chlorophyll a (CLa), chlorophyll $b$ (CLb), total chlorophyll (CLtotal), carotenoids (CAR), total chlorophyll/carotenoids ratio (CLtotal/CAR), and leaf morphophysiology: leaf area (LA), leaf dry mass (LDM), leaf mass ratio (LMR), and specific leaf area (SLA).

Determination of CLa, CLb, and CAR was performed using the third pair of fully expanded leaves, from the apical bud to the base of the plant, with a cork borer. For this, eight discs of leaf tissue were removed from the middle third of the leaves, corresponding to a total area of discs of $9.04 \mathrm{~cm}^{2}$. Then, the material was placed in small envelopes of aluminum paper and transported in thermal containers with ice to the refrigerator of the laboratory, where the samples remained totally in the dark for $48 \mathrm{~h}$ at a temperature of $8^{\circ} \mathrm{C}$. Subsequently, leaf discs were macerated in $90 \%$ acetone (5.0 $\mathrm{mL})$ and $0.2 \mathrm{~g}$ of calcium carbonate $\left(\mathrm{CaCO}_{3}\right)$. The obtained extracts were filtered using fast filter paper and collected in $25-\mathrm{mL}$ volumetric flasks completing up to volume with $80 \%$ acetone; thus, the extract was diluted five times (ARNON, 1949).

Contents of chlorophyll $a, b$, and total carotenoids were quantified through spectrophotometry with readings in absorbance (A) at the wavelengths of 663,646 , and $470 \mathrm{~nm}$, using $80 \%$ acetone as blank, through the equations $1,2,3$, and 4 , respectively, according to the methodology of Lichtenthaler
(1987):

$$
\begin{aligned}
& \mathrm{CLa}=12.21 \mathrm{~A}_{663}-2,81 \mathrm{~A}_{646} \text { Eq. } 1 \\
& \mathrm{CLb}=20.13 \times \mathrm{A}_{646}-5.03 \times \mathrm{A}_{663} \text { Eq. } 2 \\
& \text { CLtotal }=17.3 \mathrm{~A}_{646}+7.18 \mathrm{~A}_{663} \text { Eq. } 3
\end{aligned}
$$

$\mathrm{CAR}=\left(1000 \mathrm{~A}_{470}-1.82 \mathrm{CLa}-85.02 \mathrm{CLb}\right) / 198 \mathrm{Eq} .4$

The data were obtained in $\mathrm{mg} \mathrm{L}^{-1}$ and, based on the area of the leaf discs $\left(9.04 \mathrm{~cm}^{2}\right)$ and on the dilution of the extract in $80 \%$ acetone $(25 \mathrm{~mL})$, the contents of $\mathrm{CLa}, \mathrm{CLb}$, and CAR were expressed as mass per $\mathrm{m}^{2}\left(\mathrm{~g} \mathrm{~m}^{-2}\right)$.

Leaf area (LA) was determined by measuring the leaves with fully opened leaf blades, according to Lima et al. (2012), considering the following equation: $\mathrm{LA}=0.3205^{*} \mathrm{~L}^{2.0412}$, where $\mathrm{L}$ is the length of the leaf blade $(\mathrm{cm})$.

The LDM was determined after collecting leaves and drying in forced-air ovens at $65^{\circ} \mathrm{C}$ until constant weight, using a precision scale $(0.001 \mathrm{~g})$. The LMR was calculated by dividing leaf dry mass by the dry mass of the entire plant, and SLA was determined as the ratio between leaf area and leaf dry mass, according to Benincasa (2003).

The obtained data were evaluated through analysis of variance by $\mathrm{F}$ test at 0.05 and 0.01 probability levels and, in case of significance, regression analysis was performed using the statistical program SISVAR/UFLA (FERREIRA, 2011). The regression model was selected through the best fit based on the coefficient of determination $\left(\mathrm{R}^{2}\right)$.

\section{Results and Discussion}

Interaction between levels of irrigation water salinity and $\mathrm{N}$ doses had a significant effect $(\mathrm{p}<$ 0.01 and $\mathrm{p}<0.05$ ) on the contents of CLa, CL total, and CAR (Table 2). In addition, there were isolated significant effects $(p<0.01)$ of water salinity on the contents of CLb and of $\mathrm{N}$ doses $(\mathrm{p}<0.05)$ on the total CLtotal/CAR ratio. 
Table 2. Summary of the analysis of variance for chlorophyll $a$ (CLa), $b$ (CLb), and total chlorophyll (CLtotal), carotenoids (CAR) and total chlorophyll/carotenoid ratio (CLtotal/CAR) in leaves of guava seedlings cv. 'Paluma' irrigated with salinized water under nitrogen fertilization, at 190 days after emergence - DAE.

\begin{tabular}{lccccc}
\hline \multirow{2}{*}{ Source variation } & \multicolumn{5}{c}{ Mean square } \\
\cline { 2 - 6 } & CLa & CLb & CLtotal & CAR & CLtotal/CAR \\
\hline Salinity (S) & $0.6314^{* *}$ & $0.0485^{* *}$ & $0.0116^{* *}$ & $0.0857^{* *}$ & $0.2686^{\text {ns }}$ \\
Linear regression & $1.4608^{* *}$ & $0.1801^{* *}$ & $3.6436^{* *}$ & $0.3131^{* *}$ & $0.5644^{\text {ns }}$ \\
Quadratic regression & $0.1248^{\text {ns }}$ & $0.0121^{\text {ns }}$ & $0.0511^{\text {ns }}$ & $0.0139^{\text {ns }}$ & $0.0351^{\text {ns }}$ \\
N doses (ND) & $0.0933^{*}$ & $0.0078^{\text {ns }}$ & $0.1492^{\text {ns }}$ & $0.0010^{\text {ns }}$ & $0.6144^{*}$ \\
Linear regression & $0.0037^{\text {ns }}$ & $0.0088^{\text {ns }}$ & $0.0884^{\text {ns }}$ & $0.0020^{\text {ns }}$ & $0.6293^{*}$ \\
Quadratic regression & $0.0778^{*}$ & $0.0138^{\text {ns }}$ & $0.3511^{* s}$ & $0.0009^{\text {ns }}$ & $1.1426^{* *}$ \\
Interaction (S*ND) & $0.1014^{* *}$ & $0.0063^{\text {ns }}$ & $0.1368^{*}$ & $0.0213^{*}$ & $0.1926^{\text {ns }}$ \\
Blocks & $0.1067^{*}$ & $0.0035^{\text {ns }}$ & $0.1467^{\text {ns }}$ & $0.0259^{\text {ns }}$ & $0.0396^{\text {ns }}$ \\
\hline CV $(\%)$ & 15.64 & 20.64 & 15.60 & 18.30 & 13.44 \\
\hline
\end{tabular}

ns, **, *Respectively not significant and significant at $\mathrm{p}<0.01$ and $\mathrm{p}<0.05$.

In the follow-up analysis of the factor water salinity level at different $\mathrm{N}$ doses (Figure 1A), CLa data fitted to a decreasing linear regression equation as a function of the increase in water salinity in plants that received fertilization at the doses of 70 (541.1), 100 (773), and 160\% of $\mathrm{N}(1,236.8 \mathrm{mg}$ $\left.\mathrm{dm}^{-3}\right)$, and the highest values of the variable $(1.33$,
1.50 , and $\left.1.40 \mathrm{~g} \mathrm{~m}^{-2}\right)$ at the respective doses were obtained at the lowest ECw level $\left(0.3 \mathrm{dS} \mathrm{m}^{-1}\right)$, with decreases of $9.54,10.50$, and $14.50 \%$, respectively, with per unit increase in ECw. However, at $130 \%$ of $\mathrm{N}\left(1,004.9 \mathrm{mg} \mathrm{dm}^{-3}\right)$, the data best fitted to a quadratic model, with increasing effect on CLa content until the highest value $\left(1.38 \mathrm{~g} \mathrm{~m}^{-2}\right)$, at the ECw level of $1.2 \mathrm{dS} \mathrm{m}^{-1}$.

Figure 1. Follow-up analysis of the factor irrigation water salinity -ECw at the nitrogen doses for the contents of chlorophyll $a-\mathrm{CLa}$ (A) and chlorophyll $b-\mathrm{CLb}$ (B) in leaves of guava seedlings cv. 'Paluma' at 190 days after emergence-DAE.

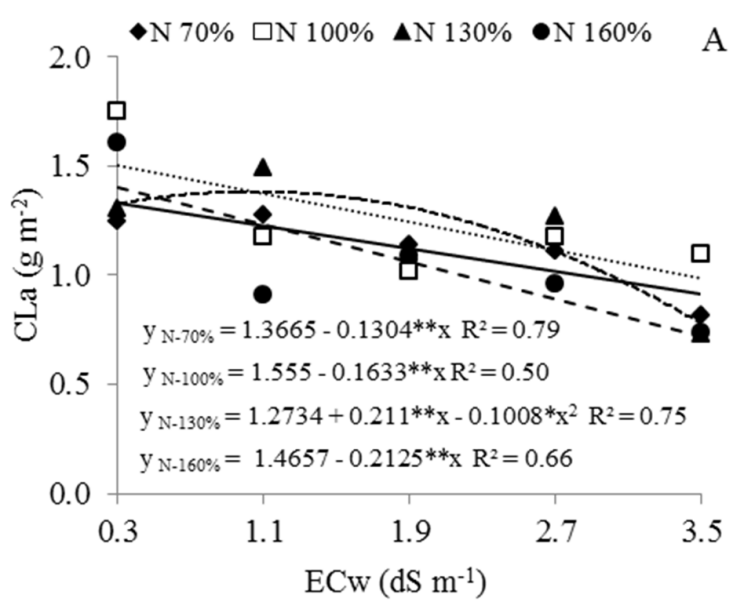

According to Munns and Tester (2008), the reduction in chlorophyll content due to the increase in salinity occurs because the salt stress stimulates the enzymatic activity of chlorophyllase, which degrades the molecules of the photosynthesizing pigments and induces structural destruction of the

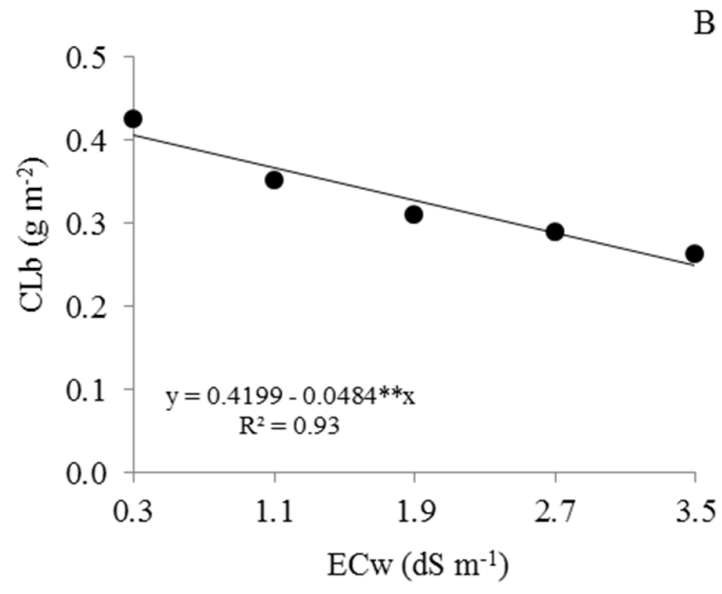

chloroplasts, besides causing loss and imbalance in the activity of pigmentation proteins. The harmful effects of irrigation water salinity on CLa contents have also been reported for passion fruit plants (CAVALCANTE et al., 2011; FREIRE et al., 2013). 
The increments in CLa contents due to the use of $\mathrm{N}$ fertilization at the dose of $130 \%$ of $\mathrm{N}(1,004.9 \mathrm{mg}$ $\mathrm{dm}^{-3}$ ) under saline conditions (Figure 1A) is related to the stimulation of $\mathrm{N}$ absorption by the plant, in relation to chloride, because of the great affinity of the plants for nitrate. The increase in $\mathrm{N}$ fertilization up to a certain dose, under saline conditions where there is $\mathrm{Cl} / \mathrm{NO}_{3}{ }^{-}$competition, can increase $\mathrm{NO}_{3}{ }^{-}$ absorption, which reduces the $\mathrm{Cl} / \mathrm{N}$ ratio in the leaves, reestablishing the nutritional balance and minimizing salt stress (BLANCO et al., 2008).

The content of CLb was negatively affected by the increment in irrigation water salinity (Figure 1B), with a linear loss of $11.53 \%\left(0.0484 \mathrm{~g} \mathrm{~m}^{-2}\right)$ per unit increase in ECw. Under these conditions, the light-capturing efficiency is reduced, since this pigment captures energy from other wavelengths and transfers it to CLa, which effectively acts in the photochemical reactions of photosynthesis, thus inhibiting photosynthetic activity and, consequently, plant growth (LIMA et al., 2011). Freire et al. (2013) also observed a deleterious effect of water salinity on CLb content in the leaves of passion fruit plants irrigated with water of $\mathrm{ECw}=4.5 \mathrm{dS} \mathrm{m}^{-1}$.

In terms of the follow-up analysis of the water salinity levels with the $\mathrm{N}$ doses for the content of CL total (Figure 2A), highest CL total values of $1.76,1.92$, and $1.84 \mathrm{~g} \mathrm{~m}^{-2}$ were obtained for plants irrigated under water salinity of $0.3 \mathrm{dS} \mathrm{m} \mathrm{m}^{-1}$ and fertilized with $\mathrm{N}$ doses of 70,100 , and $160 \%$, respectively. As water salinity increased, there were linear reductions of $10.68,12.89$, and $13.30 \%$ per unit increase in $\mathrm{ECw}$ in plants fertilized with the respective $\mathrm{N}$ doses, while at the $\mathrm{N}$ dose of $130 \%$ $\left(1,004.9 \mathrm{mg} \mathrm{dm}^{-3}\right)$, there was a quadratic effect, with increase in CL total values up to the maximum value $\left(1.78 \mathrm{~g} \mathrm{~m}^{-2}\right)$ at the water salinity level of 1.2 $\mathrm{dS} \mathrm{m}{ }^{-1}$, which was justified by the same reasons that affected CLa under this dose. In guava seedlings cv. 'Paluma', Dias et al. (2012a) observed that leaf chlorophyll content under non-saline conditions was related to the increase in $\mathrm{N}$ fertilization up to a dose of $793 \mathrm{mg}$ of $\mathrm{N} \mathrm{dm}^{-3}$ of soil.

The results obtained in plants fertilized with $\mathrm{N}$ doses of 70, 100 and 160\% (Figure 2A) are in agreement with those of Freire et al. (2013), who reported depletion of $19.2 \%$ in the content of $\mathrm{CL}$ total in passion fruit plants irrigated with $\mathrm{ECW}$ of $4.5 \mathrm{dS} \mathrm{m}^{-1}$. For Apse and Blumwald (2007), the decreases in total CL due to the increase in salinity are related to osmotic and toxic effects of the ions and to nutritional imbalance.

For CAR contents, according to the follow-up analysis of salinity levels with $\mathrm{N}$ doses (Figure $2 \mathrm{~B})$, there was no significant difference of the water salinity levels in plants fertilized with the doses of 70

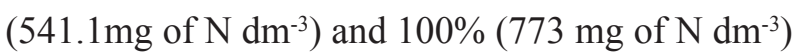
of $\mathrm{N}$. In plants fertilized with the dose of $130 \%$ of $\mathrm{N}$ $\left(1004.9 \mathrm{mg} \mathrm{dm}^{-3}\right)$, there was a quadratic effect, and the highest value $\left(0.62 \mathrm{~g} \mathrm{~m}^{-2}\right)$ was obtained at the ECw level of $1.2 \mathrm{dS} \mathrm{m}^{-1}$, while at the dose of $160 \%$ of $\mathrm{N}$ (1236.8 $\left.\mathrm{mg} \mathrm{dm}^{-3}\right)$, there was a decreasing linear effect as water salinity increased, with reductions of $11.98 \%$ in CAR content per unit increase in ECW.

The reduction in CAR content due to the increase in $\mathrm{ECW}$ can be attributed to the degradation of $\beta$-carotene under saline conditions and reduction in the synthesis of zeaxanthin, structural pigments of the carotenoids, which are apparently involved in the protection against photo-oxidative damages to chlorophyll (MUNNS; TESTER, 2008). However, this deleterious effect of salinity on CAR contents in the period of 190 DAE (Figure 2B) was lessened by $\mathrm{N}$ fertilization at the doses of 70 (541.1) and $100 \%$ of $\mathrm{N}$ ( $773.0 \mathrm{mg}$ of $\left.\mathrm{N} \mathrm{dm}^{-3}\right)$, because the plants that received these doses did not show significant difference when irrigated with water of different salinity levels up to $1.2 \mathrm{dS} \mathrm{m}^{-1}$ at the dose of $130 \%$ of $\mathrm{N}\left(1004.9 \mathrm{mg} \mathrm{dm}^{-3}\right)$, as evidenced for the CLa and CL total contents. 
Figure 2. Follow-up analysis of the factor irrigation water salinity -ECw at the nitrogen doses for the content of total chlorophyll - CLtotal (A) and carotenoids - CAR (B) in leaves of guava seedlings cv. 'Paluma' at 190 days after emergence - DAE.

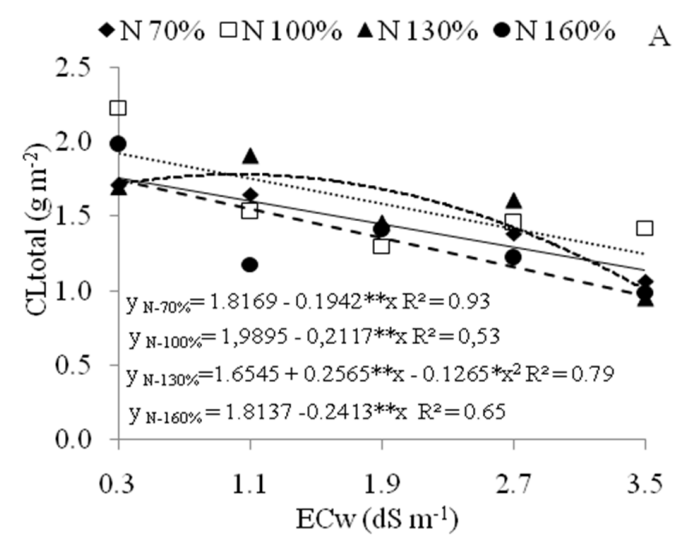

The production of CL total in relation to CAR (CLtotal/CAR) was positively influenced by the increase in $\mathrm{N}$ fertilization apparently (Figure 3), and the data best fitted to a quadratic regression equation, with the highest value $\left(2.660 \mathrm{~g} \mathrm{~m}^{-2}\right)$ at the dose of $80 \%$ of $\mathrm{N}\left(618.4 \mathrm{mg} \mathrm{dm}^{-3}\right)$. Possibly, this is due to the high correlation between $\mathrm{N}$ contents and chlorophyll in the leaves, since this nutrient is a constituent of the chlorophyll molecule (TAIZ; ZAIGER, 2013). In this case, there is a higher gain in CLa content in relation to the CAR concentration.

In terms of leaf morphophysiology (Table 3), there was a significant effect $(\mathrm{p}<0.01$ and 0.05$)$ of irrigation water salinity on leaf area (LA), leaf dry mass (LDM), and leaf mass ratio (LMR), while

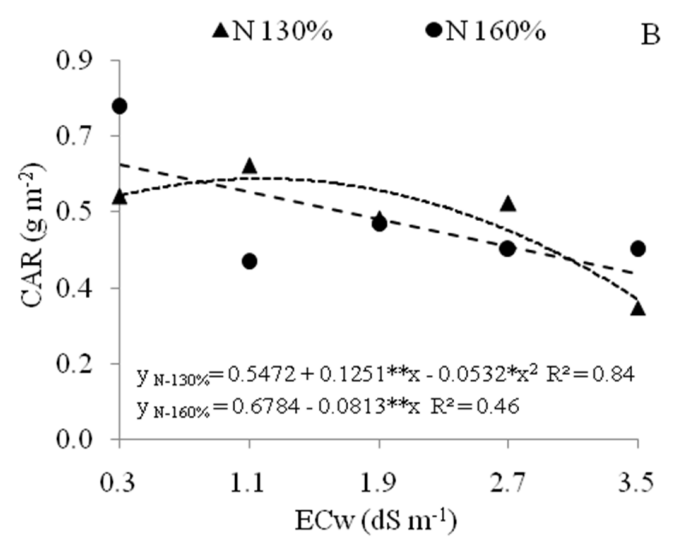

$\mathrm{N}$ doses significantly ( $\mathrm{p}<0.01$ and 0.05 ) affected LA, LDM, LMR, and SLA. However, there was no significant $(p>0.05)$ interaction between the factors water salinity and $\mathrm{N}$ doses for these variables.

According to Figure 4, leaf morphophysiology of guava seedlings, represented by LA, LDM, and LMR, was not compromised by the increase in irrigation water salinity up to a mean ECw level of $1.5 \mathrm{dS} \mathrm{m}^{-1}$, and the data of LA, LDM, and LMR were best fitted to quadratic regression equations (Figures $4 \mathrm{~A}, \mathrm{~B}$, and $\mathrm{C}$, respectively), with maximum values of $201.20 \mathrm{~cm}^{2}, 1.57 \mathrm{~g}$, and $0.442 \mathrm{~g} \mathrm{~g}^{-1}$ obtained at water salinity levels of $1.3,1.5$, and $1.7 \mathrm{dS} \mathrm{m}^{-1}$, respectively, from which there were decreases until a ECw level of $3.5 \mathrm{dS} \mathrm{m}^{-1}$.

Figure 3. Total chlorophyll/carotenoid ratio - CLtotal/CAR in leaves of guava seedlings cv. 'Paluma' as a function of nitrogen doses at 190 days after emergence - DAE.

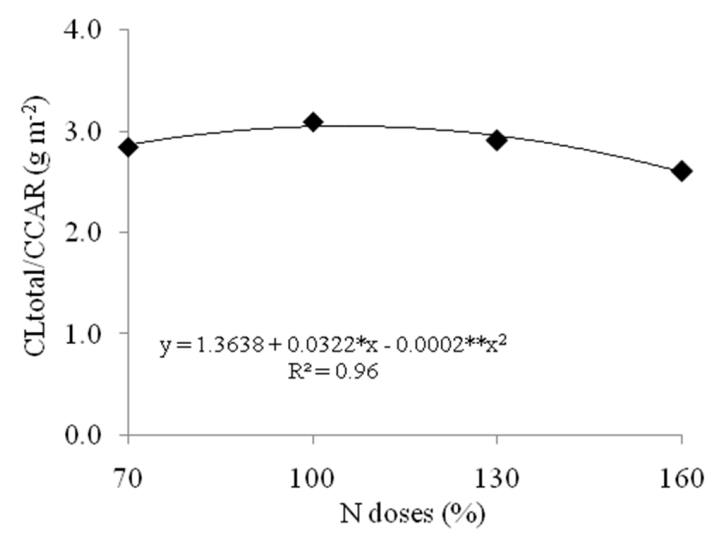


Table 3. Summary of the analysis of variance for leaf area (LA), leaf dry mass (LDM), leaf mass ratio (LMR), and specific leaf area (SLA) of guava seedlings cv. 'Paluma' irrigated with salinized water under nitrogen fertilization at 190 days after emergence - DAE.

\begin{tabular}{lcccc}
\hline \multirow{2}{*}{ Source variation } & \multicolumn{4}{c}{ Mean square } \\
\cline { 2 - 5 } & $\mathrm{LA}^{1}$ & $\mathrm{LDM}$ & $\mathrm{LMR}$ & SLA \\
\hline Salinity (S) & $23.637^{* *}$ & $0.889^{* *}$ & $0,008^{*}$ & $624,527^{\text {ns }}$ \\
Linear regression & $59.408^{* *}$ & $1.857^{* *}$ & $0,005^{\mathrm{ns}}$ & $364,357^{\text {ns }}$ \\
Quadratic regression & $29.812^{* *}$ & $1.518^{* *}$ & $0,017^{*}$ & $1828,464^{\text {ns }}$ \\
N doses (ND) & $48.082^{* *}$ & $0.723^{* *}$ & $0,014^{* *}$ & $2898,350^{*}$ \\
Linear regression & $135.455^{* *}$ & $8.111^{* *}$ & $0,039^{* *}$ & $7053,646^{* *}$ \\
Quadratic regression & $1.732^{\text {ns }}$ & $0.018^{\text {ns }}$ & $0,001^{\text {ns }}$ & $353,614^{\text {ns }}$ \\
Interaction (S*ND) & $4.380^{\text {ns }}$ & $0.137^{\text {ns }}$ & $0,001^{\text {ns }}$ & $650,711^{\text {ns }}$ \\
Blocks & $6.364^{\text {ns }}$ & $0.076^{\text {ns }}$ & $0,005^{\text {ns }}$ & $5244,360^{*}$ \\
CV $(\%)$ & 15.59 & 21.75 & 12,23 & 19,88 \\
\hline
\end{tabular}

$\mathrm{ns},{ }^{* *}, *$ Respectively not significant and significant at $\mathrm{p}<0.01$ and $\mathrm{p}<0.05 ;{ }^{1}$ statistical analysis after data transformation in .

The increase in LA up to an ECw level of $1.3 \mathrm{dS}$ $\mathrm{m}^{-1}$ must be related to some adaptive mechanisms of this species to salinity, as a consequence of the exposure time to salinity during 180 days (Fig 4A). Under salt stress conditions, there is an accumulation of wax on the leaf surface and increase in the number of the palisade and spongy cells in the leaf tissue (PARIDA; DAS, 2005), which may have resulted in an accumulation of LDM up to a salinity level of $1.5 \mathrm{dS} \mathrm{m}^{-1}$ (Figure 4B). This result is in agreement with the findings of Cavalcante et al. (2007), who observed that LDM levels of the guava cultivars 'Paluma', 'Pentecoste', and 'Surubim' increased with irrigation water salinity of up to $1.5 \mathrm{dS} \mathrm{m}^{-1}$ at 180 DAS.

In relation to LMR, it is suggested that, up to an $\mathrm{ECw}$ level of $1.7 \mathrm{dS} \mathrm{m}^{-1}$ (Figure 4C), the rate of photoassimilate exportation to the rest of the plant was lower, resulting in higher LMR, which may be related to adaptive mechanisms. Above this salinity level, the leaves tended to reach maturation early due to increased salt stress, resulting in the transport of photoassimilates to other plant parts, there by decreasing LMR. According to Rodrigues et al. (1993), LMR is a physiological component that expresses the fraction of dry mass not exported from the leaf to the rest of the plant; it tends to decrease with leaf maturation as the photoassimilated compounds are directed to other regions of the plant (BENINCASA, 2003).

In general, leaf morphophysiology responds differently to salinity in relation to the contents of photosynthetic pigments, possibly due to mechanisms of adaptation to salinity adopted by the leaves.

With regard to the isolated effect of $\mathrm{N}$ doses (Figures 5A, B, and C), the data of the variables LA, LDM, and LMR were fitted to decreasing linear regression equations, with reductions of $15.42,18.06$, and $5.31 \%$ in the respective variables. With the highest values obtained at the lowest dose, i.e., $70 \%$ of $\mathrm{N}\left(541.1 \mathrm{mg}\right.$ of $\left.\mathrm{N} \mathrm{dm}^{-3}\right)$, this dose was close to the concentration of $552 \mathrm{mg}$ of $\mathrm{N}_{\text {plant }}{ }^{-1}$ accumulated in guava seedlings cv. 'Paluma' in a hydroponic cultivation system (FRANCO et al., 2007). It can be inferred that increasing $\mathrm{N}$ fertilization beyond a dose of $541.1 \mathrm{mg} \mathrm{dm}^{-3}$, using urea as $\mathrm{N}$ source, inhibits leaf morphophysiology by increasing soil ammonium levels, which may cause plant toxicity as observed by Silva et al. (2014) for jackfruit seedlings.

Increased $\mathrm{N}$ doses stimulated SLA, and the data best fitted to an increasing linear regression equation, with increment of $7.95 \%$ for every $30 \%$ increase in $\mathrm{N}$ dose $\left(231.9 \mathrm{mg}\right.$ of $\mathrm{N} \mathrm{dm}^{-3}$ ) (Figure 
5 D). According to Benincasa (2003), SLA is a is related to the lesser thickness of the leaf blade physiological component that relates leaf surface to and to the reduction in leaf lignification, resulting the dry mass of the leaf itself, and the increase in in lighter leaves, contributing to increasing leaf area this variable with the increment in $\mathrm{N}$ fertilization per unit of mass (PEREIRA et al., 2012).

Figure 4. Leaf area - LA, leaf dry mass - LDM and leaf mass ratio - LMR of guava seedlings cv. 'Paluma' as a function of irrigation water salinity at 190 days after emergence - DAE.

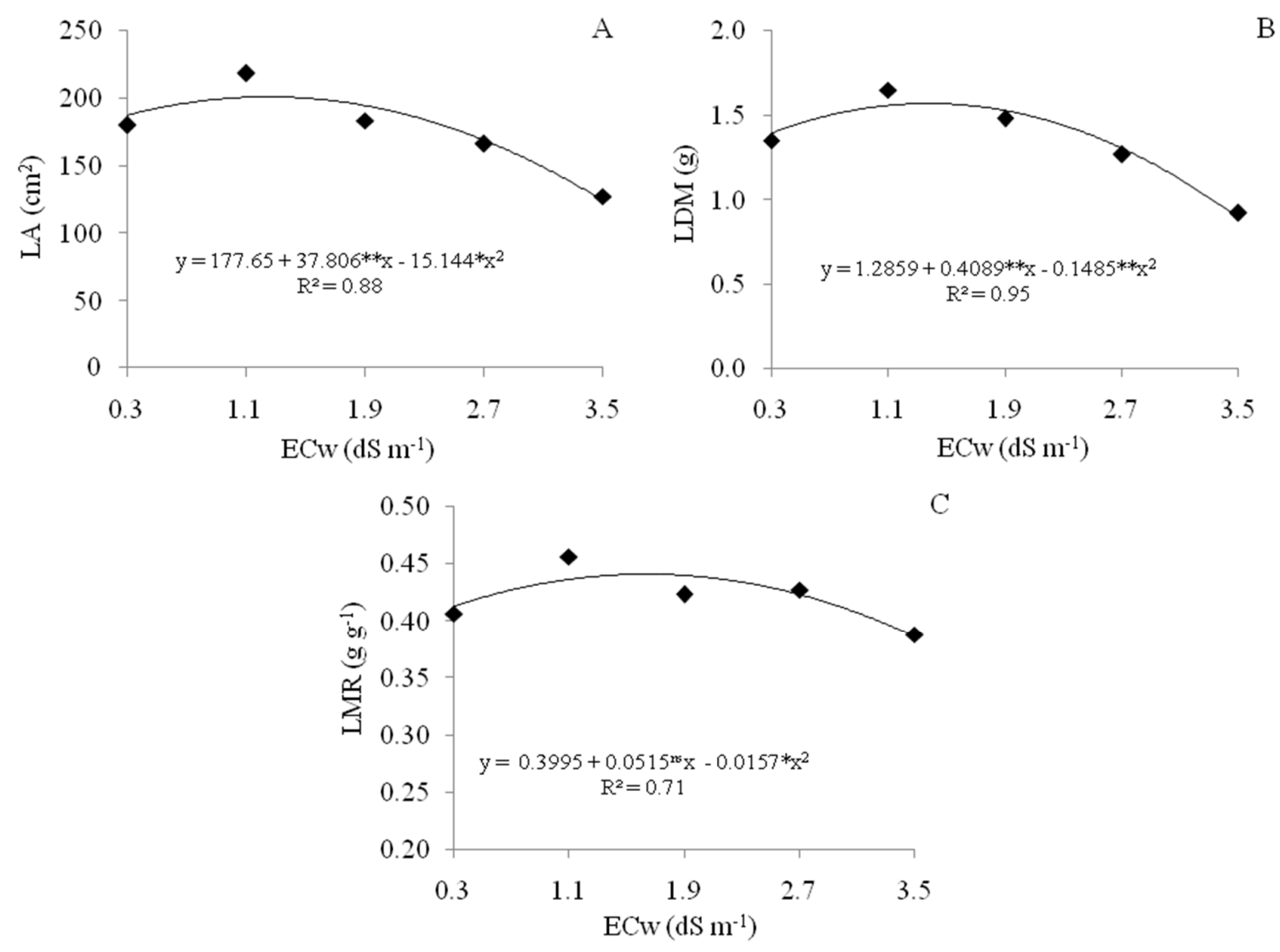


Figure 5. Leaf area - LA (A), leaf dry mass - LDM (B), leaf mass ratio - LMR (C), and specific leaf area - SLA (D) of guava seedlings cv. 'Paluma' as a function of nitrogen doses at 190 days after emergence - DAE.
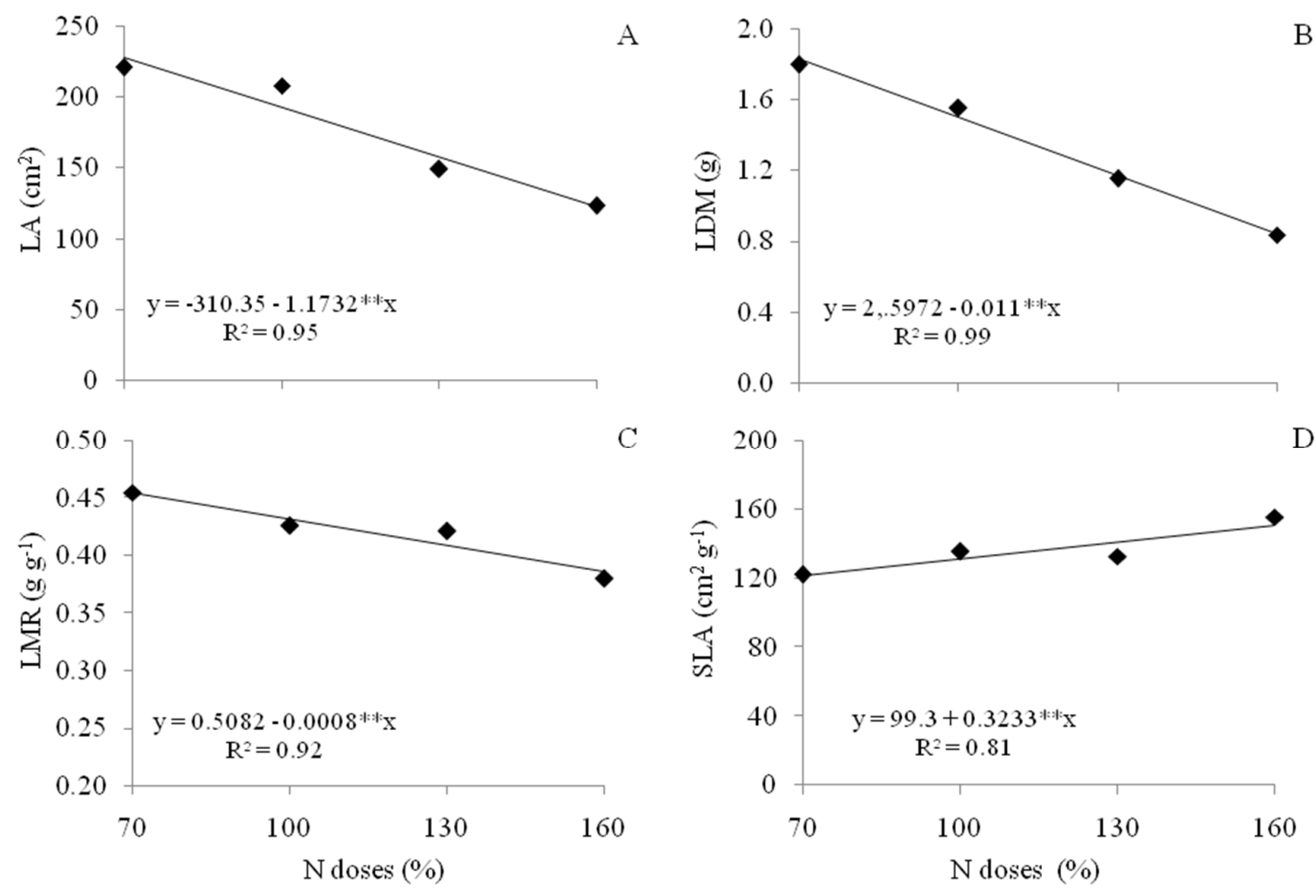

\section{Conclusions}

\section{Acknowledgments}

The contents of photosynthetic pigments in the leaves of guava seedlings cv. 'Paluma' are inhibited by the increase in irrigation water salinity, while leaf morphophysiology is not compromised by irrigation with mean water salinity of up to $1.5 \mathrm{dS}$ $\mathrm{m}^{-1}$ at 190 days after emergence.

Salt stress on the contents of chlorophyll $a, \mathrm{CL}$ total, and carotenoids is lessened with nitrogen fertilization at the dose of $1,004.9 \mathrm{mg}$ of $\mathrm{N} \mathrm{dm}^{-3}$ of soil up to an irrigation water salinity level of $1.2 \mathrm{dS}$ $\mathrm{m}^{-1}$.

Nitrogen fertilization higher than $541.1 \mathrm{mg}$ of $\mathrm{N} \mathrm{dm}{ }^{-3}$ of soil, regardless of the salinity level, is deleterious for leaf morphophysiological variables.

Thanks to the National Council for Scientific and Technological Development - CNPq, 2013 Universal Call, for funding this research and to the Federal University of Campina Grande - UFCG/ CCTA, for providing the infrastructure facilities.

\section{References}

APSE, M. P.; BLUMWALD, E. $\mathrm{Na}^{+}$transport in plants. FEBS Letters, Oxford, v. 581, n. 12, p. 2247-2254, 2007.

ARNON, D. I. Copper enzimes in isolated chloroplasts. Polyphenoloxidases in Beta vulgaris. Plant Physiology, Waterbury, v. 24, n. 1, p. 1-15, 1949.

BENINCASA, M. M. P. Análise de crescimento de plantas, noções básicas. 2. ed. Jaboticabal: FUNEP, 2003. $41 \mathrm{p}$. 
BLANCO, F. F.; FOLEGATTI, M. V.; HENRIQUES NETO, D. Doses de N e K no tomateiro sob estresse salino: I. Concentração de nutrientes no solo e na planta. Revista Brasileira de Engenharia Agrícola e Ambiental, Campina Grande, v. 12, n. 1, p. 26-33, 2008.

CAVALCANTE, Í. H. L.; CAVALCANTE, L. F.; HU, Y.; BECKMANN-CAVALCANTE, M. Z. Water salinity and initial development of four guava (Psidium guajava L.) cultivar in north-eastern Brazil. Fruit and Ornamental Plant Research, Skierniewice, v. 15, n. 1, p. 71-80, 2007.

CAVALCANTE, L. F.; DIAS, T. J.; NASCIMENTO, R.; FREIRE, J. L. O. Clorofila e carotenoides em maracujazeiro-amarelo irrigado com águas salinas no solo com biofertilizante bovino. Revista Brasileira de Fruticultura, Jaboticabal, v. 33, n. 1, 699-705, 2011.

CAVALCANTE, L. F; VIEIRA, M. S.; SANTOS, A. F.; OLIVEIRA, W. M.; NASCIMENTO, J. A. M. Água salina e esterco bovino líquido na formação de mudas de goiabeira cultivar Paluma. Revista Brasileira de Fruticultura, Jaboticabal, v. 32, n. 1, p. 251-261, 2010.

CLAESSEN, M. E. C. (Org.). Manual de métodos de análise de solo. 2. ed. rev. atual. Rio de Janeiro: EmbrapaCNPS, 1997. 212 p.

CORREAA, M. C. M.; PRADO, R. M.; NATALE, W.; PEREIRA, L.; BARBOSA, J. C. Respostas de mudas de goiabeira a doses e modos de aplicação de fertilizante fosfatado. Revista Brasileira de Fruticultura, Jaboticabal, v. 25, n. 1, p. 164-169, 2003.

DIAS, M. J. T.; SOUZA, H. A.; NATALE, W.; MODESTO, V. C.; ROZANE, D. E. Adubação com nitrogênio e potássio em mudas de goiabeira em viveiro comercial. Semina: Ciências Agrárias, Londrina, v. 33, p. 2837-2848, 2012a. Suplemento 1.

DIAS, T. J.; CAVALCANTE, L. F.; NUNES, J. C.; FREIRE, J. L. de O.; NASCIMENTO, J. A. M. Qualidade física e produção do maracujá amarelo em solo com biofertilizante irrigado com águas salinas. Semina: Ciências Agrárias, Londrina, v. 33, p. 2905-2918, 2012 b. Suplemento 1.

FERREIRA, D. F. Sisvar: a computer statistical analysis system. Ciência e Agrotecnologia, Lavras, v. 35, n. 6, p. 1039-1042, 2011.

FRANCO, F. C.; PRADO, R. M.; BRACHIROLLI, L. F.; ROZANE, D. E. Curva de crescimento e marcha de absorção de macronutrientes em mudas de goiabeira. Revista Brasileira de Ciência do Solo, Viçosa, MG, v. 31, n. 6, p. 1429-1437, 2007.

FREIRE, J.L. O.; CAVALCANTE, L.F.; NASCIMENTO, R.; REBEQUI, A. M. Teores de clorofila e composição mineral foliar do maracujazeiro irrigado com águas salinas e biofertilizante. Revista de Ciências Agrárias, Recife, v. 36, n. 1, p. 57-70, 2013.

HOLANDA, J. S.; AMORIM, J. R. A.; FRRREIRA NETO, M.; HOLANDA, A. C. Qualidade da água para irrigação. In: GHEYI, H. R.; DIAS, N. S.; LACERDA, C. F. (Ed.). Manejo da salinidade na agricultura: estudos básicos e aplicados. Fortaleza: INCTSal, 2010. p. 43-61.

LICHTENTHALER, H. K. Chlorophylls and carotenoids: pigments of photosynthetic biomembranes. In: PACKER, L.; DOUCE, R. Methods in enzimology. London: Academic Press, 1987. v. 148, p. 350-381.

LIMA, L. G. S.; ANDRADE, A. C.; SILVA, R. T. L.; FRONZA, D.; NISHIJIMA, T. Modelos matemáticos para estimativa de área foliar de goiabeira (Psidium guajava L.). In: REUNIÃO ANUAL DA SOCIEDADE BRASILEIRA PARA O PROGRESSO DA CIÊNCIA, SBPC, 64., 2012, São Luiz. Anais... São Luiz: UFMA, 2012. Available in: <http://www.sbpcnet.org.br/ livro/64ra/resumos/resumos/3478.htm $>$. Access at: sept. $18,2014$.

LIMA, M. C.; AMARANTE, L.; MARIOT, M. P.; SERPA, R. Crescimento e produção de pigmentos fotossintéticos em Achilleamille folium L. cultivada sob diferentes níveis de sombreamento e doses de nitrogênio. Ciência Rural, Santa Maria, v. 41, n. 1, p. 45-50, 2011.

MEDEIROS, J. F. Qualidade da água de irrigação e evolução da salinidade nas propriedades assistidas pelo GAT nos Estado do RN, PB e CE. 1992. Dissertação (Mestrado em Engenharia Agrícola) - Universidade Federal da Paraíba, Campina Grande.

MUNNS, R.; TESTER, M. Mechanisms of salinity tolerance. Annual Review of Plant Biology, New York, v. 59, n. 1, p. 651-681, 2008.

PARIDA, A. K.; DAS, A. B. Salt tolerance and salinity effects on plants: a review. Ecotoxicology and Environmental Safety, New York, v. 60, n. 3, p. 324-349, 2005.

PEREIRA, O. G.; ROVETTA, R.; RIBEIRO, K. G.; SANTOS, M. E. R.; FONSECA, D. M.; CECON, P. R. Crescimento do capim-tifton 85 sob doses de nitrogênio e alturas de corte. Revista Brasileira de Zootecnia, Viçosa, MG, v. 41, n. 1, p. 30-35, 2012.

RODRIGUES, J. D.; RODRIGUES, S. D.; PEDRAS, J. F.; DELACHIAVE, M. E. A.; BOARO, C. S. F.; ONO, E. O. Diferentes níveis de cálcio e o desenvolvimento de plantas de estilosantes (Stylosanthes guianensis (AUBL.) Sw. Cv cook). Scientia Agrícola, Piracicaba, v. 50, n. 2, p. 
166-175, 1993.

SILVA, C. P.; GARCIA, K. G. V.; TOSTA, M. S.; CUNHA, C. S. M.; NASCIMENTO, C. D. V. Adubação nitrogenada no crescimento inicial de mudas de jaqueira. Enciclopédia Biosfera, Goiânia, v. 10, n. 18, p. 174-180, 2014.

TAIZ, L.; ZEIGER, E. Fisiologia vegetal. 5. ed. Porto
Alegre: Artmed, 2013. 954 p.

TATAGIBA, S. D.; MORAES, G. A. B. K.; NASCIMENTO, K. J. T.; PELOSO, A. F. Limitações fotossintéticas em folhas de plantas de tomateiro submetidas a crescentes concentrações salinas. Engenharia na Agricultura, Viçosa, MG, v. 22, n. 2, p. 138-149, 2014.

TÁVORA, F. J. A. F.; FERREIRA, R. G.; HERNANDEZ, F. F. F. Crescimento e relações hídricas em plantas de goiabeira submetidas a estresse salino com $\mathrm{NaCl}$. Revista Brasileira de Fruticultura, Jaboticabal, v. 23, n. 2, p. 441-446, 2001. 